\title{
RESEARCH
}

Open Access

\section{Inter-center comparison of good manufacturing practices-compliant stromal vascular fraction and proposal for release acceptance criteria: a review of 364 productions}

Pauline François ${ }^{1,2}$, Giulio Rusconi ${ }^{3,4}$, Laurent Arnaud ${ }^{5}$, Luca Mariotta ${ }^{3}$, Laurent Giraudo ${ }^{1}$, Greta Minonzio ${ }^{3}$, Julie Veran ${ }^{1}$, Baptiste Bertrand ${ }^{6}$, Chloé Dumoulin ${ }^{1}$, Fanny Grimaud ${ }^{1}$, Luc Lyonnet ${ }^{5}$, Dominique Casanova ${ }^{6}$, Camille Giverne', Audrey $\mathrm{Cras}^{8}$, Guy Magalon ${ }^{9}$, Françoise Dignat-George ${ }^{2,5}$, Florence Sabatier ${ }^{1,2,9}$, Jeremy Magalon ${ }^{1,2,9^{*}+}$ and Gianni Soldati ${ }^{3+}$

\begin{abstract}
Background: Even though the manufacturing processes of the stromal vascular fraction for clinical use are performed in compliance with the good manufacturing practices applying to advanced therapy medicinal products, specifications related to stromal vascular fraction quality remain poorly defined. We analyzed stromal vascular fraction clinical batches from two independent good manufacturing practices-compliant manufacturing facilities, the Swiss Stem Cell Foundation (SSCF) and Marseille University Hospitals (AP-HM), with the goal of defining appropriate and harmonized release acceptance criteria.

Methods: This retrospective analysis reviewed the biological characteristics of 364 batches of clinical-grade stromal vascular fraction. Collected data included cell viability, recovery yield, cell subset distribution of stromal vascular fraction, and microbiological quality.

Results: Stromal vascular fraction from SSCF cohort demonstrated a higher viability $(89.33 \% \pm 4.30 \%)$ and recovery yield $\left(2.54 \times 10^{5} \pm 1.22 \times 10^{5}\right.$ viable nucleated cells (VNCs) per $\mathrm{mL}$ of adipose tissue) than stromal vascular fraction from AP-HM (84.20\% $\pm 5.96 \%$ and $2.25 \times 10^{5} \pm 1.11 \times 10^{5} \mathrm{VNCs}$ per $\left.\mathrm{mL}\right)$. AP-HM batches were significantly less contaminated ( $95.71 \%$ of sterile batches versus $74.15 \%$ for SSCF batches). The cell subset distribution was significantly different (higher proportion of endothelial cells and lower proportion of leukocytes and pericytes in SSCF cohort).
\end{abstract}

\footnotetext{
* Correspondence: Jeremy.magalon@ap-hm.fr

Jeremy Magalon and Gianni Soldati share last authorship.

'Cell Therapy Department, Hôpital de la Conception, AP-HM, INSERM CIC BT

1409, 147 Bd Baille, 13005 Marseille, France

${ }^{2}$ Aix Marseille Univ, INSERM, INRA, C2VN, Marseille, France

Full list of author information is available at the end of the article
}

C C The Author(s). 2021 Open Access This article is licensed under a Creative Commons Attribution 4.0 International License, which permits use, sharing, adaptation, distribution and reproduction in any medium or format, as long as you give appropriate credit to the original author(s) and the source, provide a link to the Creative Commons licence, and indicate if changes were made. The images or other third party material in this article are included in the article's Creative Commons licence, unless indicated otherwise in a credit line to the material. If material is not included in the article's Creative Commons licence and your intended use is not permitted by statutory regulation or exceeds the permitted use, you will need to obtain permission directly from the copyright holder. To view a copy of this licence, visit http://creativecommons.org/licenses/by/4.0/. The Creative Commons Public Domain Dedication waiver (http://creativecommons.org/publicdomain/zero/1.0/) applies to the data made available in this article, unless otherwise stated in a credit line to the data. 
Conclusions: Both centers agreed that a good manufacturing practices-compliant stromal vascular fraction batch should exert a viability equal or superior to $80 \%$, a minimum recovery yield of $1.50 \times 10^{5} \mathrm{VNCs}$ per $\mathrm{mL}$ of adipose tissue, a proportion of adipose-derived stromal cells at least equal to $20 \%$, and a proportion of leukocytes under 50\%. In addition, a multiparameter gating strategy for stromal vascular fraction analysis is proposed.

Keywords: Stromal vascular fraction, Adipose tissue, Cell subset distribution, Flow cytometry, GMP production, Advanced therapy medicinal product

\section{Background}

The stromal vascular fraction (SVF) is an heterogeneous cell population extracted from adipose tissue (AT) [1-3]. For several years, it has been classified as an advanced therapy medicinal product (ATMP) and evaluated in multiple clinical trials for its regenerative ability. Indeed, initially formalized by Bourin et al., the SVF contains at least $15 \%$ of mesenchymal stromal/stem cells (MSCs) also called adipose-derived stromal cells (ASCs), 10 to $20 \%$ of endothelial cells and progenitors (ECs), and about $4 \%$ of pericytes (PRs). These different cell subsets cooperate to promote synergistic angiogenic, immunomodulatory, and trophic effects [4]. SVF also contains blood cells and notably leucocytes (Leuk) although their exact contribution to the biological effect of SVF is not elucidated.

As an ATMP, the SVF must be produced in compliance with the good manufacturing practices (GMP) and thus necessitates quality controls during production, mainly in order to ensure cleanliness of the production area and inherent sterility of the final product. The viability of the cell product is always determined as it conditions cell integrity and function and is essential to ensure a potential therapeutic effect. In this context, SVF viability is often considered as the main specification of the final ATMP. As well as the viability, the cell recovery rate or cell yield corresponding to the number of viable nucleated cells (VNCs) obtained per $\mathrm{mL}$ of AT is usually estimated and is a good indicator of the extraction efficiency. Indeed, it is now well established that technical settings associated to AT processing can influence SVF characteristics and efficacy. They include both conditions of AT harvesting such as the harvesting area [5], the harvesting technique [6,7], and conditions of manufacturing $[8,9]$ according to whether they are manual or automated, enzymatic, or mechanic [10-14]. Furthermore, flow cytometry is classically used to define the distribution of the main nucleated cell subsets within isolated SVF, as the best approach to approximate the SVF composition. Because of the diversity of potential mechanisms of action associated to in vivo delivery of SVF, and the difficulty to anticipate them through in vitro testing, its cellular composition is currently viewed as surrogate marker of SVF potency. However, flow cytometry analysis of clinical grade SVF and results' interpretation is crucially limited by a lack of standardization. Although guidelines are available and indicate which markers should be used to identify each SVF cell population, no consensus emerges when looking at a large body of articles [15-20]. The SVF composition is highly different according to studies and no reference values exist to qualify SVF prior to clinical use. This issue also compromises the identification of a potential relationship between SVF composition and therapeutic activity.

In an attempt to contribute to a better harmonization and standardization of practices in the field of SVFbased therapy, we conducted a retrospective analysis of a large number of clinical-grade SVF batches released by two nationally authorized GMP-compliant cell therapy facilities: the Swiss Stem Cell Foundation (SSCF) in Switzerland and the cell therapy department of Marseille University Hospital (AP-HM) in France. The objective was to compare the manufacturing processes and SVF biological attributes resulting from quality control testing in order to define a control strategy and delineate relevant thresholds for release acceptance criteria.

\section{Methods \\ Donor specifications}

AT was obtained from two cohorts of patients included either in the service offered by SSCF, Switzerland, for aesthetic purpose or in the French clinical trials listed in supplemental table 1. For the latter, AT harvesting was performed in the department of plastic surgery, La Conception, University Hospital, Marseille, France. The study was conducted in accordance with the Declaration of Helsinki, and all subjects provided informed consent. If necessary, studies were approved by national ethics committee review board (supplemental table 1) between January 2013 and middle 2019.

\section{Adipose tissue harvesting}

For the SSCF cohort, AT harvesting was performed in an operating room under general anesthesia. AT was collected in three $60-\mathrm{ml}$ syringes filled with a maximum of $50 \mathrm{ml}$ each with various cannula; syringes were inserted in a double secondary container (2 labeled envelopes), then delivered to SSCF in a dedicated transport 
container at room temperature $\left(20 \pm 10^{\circ} \mathrm{C}\right)$. The AT sample was processed within $24 \mathrm{~h}$ after collection.

For the AP-HM cohort, AT harvesting was performed in an operating room under general or local anesthesia after a standardized skin aseptic preparation using a Khouri cannula (Khouri Harvester, Koume, Lipoplasty Products, Sunrise, FL, USA), a 12-gauge 12-hole multiperforated cannula, through a closed circuit, preventing contamination of the harvested product. Then, the AT was packaged in a bag (Easyflex+, Macopharma, Mouvaux, France). Once harvesting was complete, the bag was transported to the cell therapy unit and the AT was immediately processed.

\section{SVF manufacturing}

In the SSCF facilities, AT was washed twice with Dulbecco's phosphate-buffered saline with calcium and magnesium solution (DPBS +/+, Gibco, Life Technologies, Carlsbad, CA, USA) and enzymatically digested for $45 \mathrm{~min}$ at $37^{\circ} \mathrm{C}$ under constant agitation in a cell culture incubator. For the latter, Liberase ${ }^{\circ}$ MNP-S (Roche, Basel, Switzerland), i.e., a mix of collagenase I and II, and neutral proteases, was used. Enzymatic digestion was then stopped with sterile, clinical grade 1\% human serum albumin (HSA, CSL Behring, King of Prussia, PA, USA) in DPBS without calcium and magnesium (DPBS -/-, Life Technologies); the hydrophilic phase was collected and subsequently filtered with $100-\mu \mathrm{m}$ and $40-\mu \mathrm{m}$ sieves. At the final step of SVF manufacturing, the hydrophilic phase was centrifuged and the resulting cell pellet, i.e., the autologous SVF, was resuspended in 5\% HSA.

In the AP-HM facilities, the autologous SVF was obtained using the Celution 800/CRS automated processing system (Lorem Cytori, San Diego, CA, USA) according to the manufacturer's instructions. Briefly, the collected lipoaspirate was washed with Ringer's lactate (RL; Baxter, Deerfield, IL, USA) and enzymatically digested with Celase, a GMP cocktail of enzymes provided with consumables (Worthington Biochemical Corp., Lakewood, NJ, USA). The cells were concentrated, washed, aseptically recovered, and resuspended in RL.

\section{Viable nucleated cell concentration and cell viability}

For both cohorts, the number of VNCs and percentage of cell viability were determined using a NucleoCounter NC-100 instrument (ChemoMetec, Allerød, Denmark). Recovery yield was calculated as the number of total VNCs obtained divided by the initial volume of AT measured after removal of infiltration liquid (decantation).

\section{Microbiological testing and environmental monitoring}

For both cohorts, a microbiological testing was performed on the end product consisting in inoculating SVF samples in Bact/Alert culture bottles (aerobic and anaerobic culture vials, each containing $40 \mathrm{~mL}$ of medium). The Bact/Alert method (Biomerieux, Marcy l'Etoile, France) uses a computer-controlled incubation/ detection system. The media used contained proprietary factors designed to inactivate a wide variety of antibacterial and antifungal agents. Bact/Alert culture bottles were incubated at $37^{\circ} \mathrm{C}$ and $5 \% \mathrm{CO}_{2}$ for a total of 10 days (AP-HM) or 14 days (SSCF), and automated readings were taken every 10 min (according to the European Pharmacopoeia - Chapter 2.6.27 Microbiological Examination of cell-based Preparations). Detection of organisms resulted in an audible alarm and automatic recording of time of detection.

Some "in process" environmental monitoring quality controls were also carried out in both facilities, consisting in contact agar, gloves fingerprints, or air impacting. The environmental controls details and a summary of both protocols are exposed in Table 1.

\section{Flow cytometry analysis of SVF cell subsets Immunolabeling of SVF cells}

For SSCF cohort, the SVF cells were characterized by cytofluorimetric analysis using a 10 channel Navios cytometer (Beckman Coulter, Nyon, Switzerland). Briefly, $500,000 \mathrm{VNCs}$ were sampled and centrifuged $5 \mathrm{~min}$ at $400 \mathrm{~g}$. The pellet was resuspended in $220 \mu \mathrm{L}$ of DPBS without calcium and magnesium (Life Technologies) supplemented with $1 \%$ human serum off the clot (PAA Laboratories, Inc); then, $100 \mu \mathrm{L}$ of the cell suspension was distributed into two test tubes and stained with the Syto40 nuclear marker, the 7AAD viability marker and antibodies or corresponding isotype controls in matched concentrations. The monoclonal antibody mix, ready to use and lyophilized (Beckman Coulter), included antibodies directed against CD146, CD45, and CD34, conjugated with the following fluorochromes: PE, KRO, and APCA750 respectively (references listed in supplemental table 2). After $20 \mathrm{~min}$ of incubation, erythrocytes were lysed with $1 \mathrm{~mL}$ of VersaLyse (Beckman Coulter). Before acquisition, $100 \mu \mathrm{L}$ of Perfect-Count Microspheres (Cytognos, Salamanca, Spain) was added to the test tube. Data files were analyzed using Kaluza software (Beckman Coulter).

For AP-HM cohort, characterization of the SVF cell sub-populations was performed by flow cytometry using also a 10 channel Navios instrument (Beckman Coulter, Brea, CA, USA). Aliquots of 500,000 VNCs per tube were resuspended in $100 \mu \mathrm{L}$ of DPBS, after centrifugation $5 \mathrm{~min}$ at $400 \mathrm{~g}$, and stained for $20 \mathrm{~min}$ at room temperature in the dark with the DRAQ5 nuclear 
Table 1 Comparative description of SSCF and AP-HM methods. Comparative description of each critical steps of SVF manufacturing and associated quality controls performed at the SSCF and AP-HM cell-therapy facilities. DPBS Dulbecco's phosphate-buffered saline, HSA human serum albumin, RL Ringer's lactate

\begin{tabular}{|c|c|c|c|}
\hline & SSCF & \multicolumn{2}{|l|}{ AP-HM } \\
\hline Adipose tissue harvesting & Manual or automatic harvesting using various canula & \multicolumn{2}{|c|}{$\begin{array}{l}\text { Manual harvesting using a Khouri Cannula after a strict aseptic skin } \\
\text { preparation }\end{array}$} \\
\hline Settling & $10 \mathrm{~min}$ & \multicolumn{2}{|l|}{$5 \mathrm{~min}$} \\
\hline Packaging in syringes & Directly packaging in 60-mL Luer Lock syringes. & \multicolumn{2}{|c|}{ Packaging in 60-mL Luer Lock syringes from a bag } \\
\hline Device preparation & Manual collection of AT & \multicolumn{2}{|c|}{$\begin{array}{l}\text { Tensioning the Celution }{ }^{\circledR} \text { device, settlement of consumables, and } \\
\text { seal check }\end{array}$} \\
\hline Adipose tissue transfer & Into three $100-\mathrm{ml}$ syringes & \multicolumn{2}{|c|}{ AT transfer in the Celution ${ }^{\oplus}$ device } \\
\hline Settling & $10 \mathrm{~min}$ & Automated & Visual check of discarding infiltration liquid \\
\hline Infiltration liquid removal & Yes & & \\
\hline Weighing & $150 \mathrm{ml}$ of AT required & & At least $100 \mathrm{~mL}$ of AT required \\
\hline Washing & Twice with DPBS +/+ & & From two to five washings with RL and visual check \\
\hline Addition of the enzyme & Addition of Liberase ${ }^{\circledast}$ & \multicolumn{2}{|c|}{ Addition of Celase ${ }^{\circledast}$ in the device } \\
\hline Adipose tissue digestion & $45 \mathrm{~min}$ at $37^{\circ} \mathrm{C}$ & Automated & 20 min at room temperature \\
\hline Washing & DPBS $-/-+1 \% \mathrm{HSA}$ & Automated & With RL \\
\hline Filtration & $100 \mu \mathrm{m}$ and $40 \mu \mathrm{m}$ & \multicolumn{2}{|l|}{ NA } \\
\hline Collection of the SVF & SVF resuspended in 5\% HSA & \multicolumn{2}{|c|}{ SVF resuspended in $\mathrm{RL}$} \\
\hline Quality control sampling & $\begin{array}{l}\text { 1) Cell count and viability } \\
\text { 2) Evaluation of cell subset distribution with flow cytometry }\end{array}$ & \multicolumn{2}{|c|}{$\begin{array}{l}\text { 1) Cell count and viability } \\
\text { 2) Evaluation of cell subset distribution with flow cytometry } \\
\text { 3) CFU-F assay }\end{array}$} \\
\hline Quality control of the end product & Microbiological control & \multicolumn{2}{|c|}{ Microbiological control } \\
\hline Environnemental control in process & $\begin{array}{l}\text { 1) Passive agar ( } A \text { class) }(2 x) \\
\text { 2) Contact agar bench }(2 x) \\
\text { 3) Gloves fingerprints after SVF packaging ( } 2 x) \\
\text { 4) Air impacting ( } A \text { and } B \text { class) }\end{array}$ & \multicolumn{2}{|c|}{$\begin{array}{l}\text { 1) Passive agar (B class) } \\
\text { 2) Passive agar (A class) } \\
\text { 3) Gloves fingerprints after AT transfer } \\
\text { 4) Gloves fingerprints after enzyme reconstitution and transfer } \\
\text { 5) Gloves fingerprints after SVF collection } \\
\text { 6) Contact agar bench } \\
\text { 7) Contact agar working area } \\
\text { 8) Gloves fingerprints after SVF packaging } \\
\text { 9) Contact agar working area } \\
\text { 10) Air impacting (A and B class) }\end{array}$} \\
\hline
\end{tabular}

marker and ready to use antibody mixes or corresponding isotype controls in matched concentrations. The monoclonal antibodies mix included antibodies against CD90, CD146, CD34, and CD45, conjugated with the following fluorochromes: FITC, PE, ECD, and PC5 respectively (references listed in supplemental table 2). Red blood cells were lysed in $\mathrm{NH}_{4} \mathrm{Cl}$ for 10 min before the cells were centrifuged and resuspended in DPBS without calcium and magnesium (Life Technologies). Then, NucBlue (Thermo Fisher Scientific), which allows discrimination of viable and dead cells, was added for 5 min prior to flow cytometry analysis. Data files were analyzed using Kaluza software (Beckman Coulter).

\section{Inter-center validation of a common flow cytometry gating strategy}

In order to be able to reliably compare the flow cytometry data generated by each center, we first verified that the difference in the antibodies panel used by the two facilities did not hamper the comparability of data when a common gating strategy is used. To that aim, 14 SVF batches manufactured in the two centers using a similar manual digestion protocol [21] were immunolabeled using the SSCF antibodies panel and the AP-HM antibodies panel. Samples were then analyzed by the same operator using the same defined gating strategy using Kaluza software as follows (Fig. 1):

\section{Common gating strategy}

1) Nucleated cells (NCs) were selected according to the nuclear marker used (DRAQ5 or Syto40).

2) Aggregates were removed using the forward scatter.

3) Viable nucleated cells (VNCs) were determined based on the death marker (NucBlue or 7-AAD).

4) Among VNCs, the CD45 marker was used to discriminate the hematopoietic CD45+ cells from the non-hematopoietic regenerative cells CD45-.

5) A density plot CD146 versus CD34, gated on the CD45- cells, allowed the identification of ASCs (CD45-CD34+CD146-), EC (CD45$\mathrm{CD} 34+\mathrm{CD} 146+)$, and an heterogeneous populations containing PRs and transitional cells (CD45-CD34CD146+). 

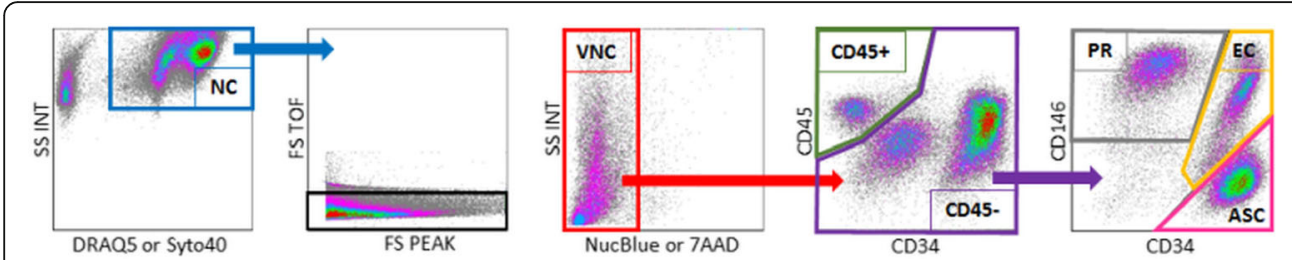

\begin{tabular}{|c|c|c|}
\hline & SSCF & AP-HM \\
\hline $\begin{array}{c}\text { Nuclear } \\
\text { marker }\end{array}$ & Syto40 & DRAQ5 \\
\hline $\begin{array}{c}\text { Viability } \\
\text { marker }\end{array}$ & 7-AAD & NucBlue \\
\hline CD45 & KrO & PC5 \\
\hline CD34 & AA750 & ECD \\
\hline CD146 & PE & PE \\
\hline
\end{tabular}

Fig. 1 The common gating strategy. Presentation of the common gating strategy and reminder of the fluorochromes conjugated according to the initial protocol of each center. EC, endothelial cell; ASC, adipose-derived stromal cell; PR, pericyte; SS, size scatter; FS, forward scatter; NC, nucleated cell; VNC, viable nucleated cell

That strategy leads to a complete characterization of the SVF, meaning the addition of the proportions of ASCs, ECs, PRs, and transitional cells and hematopoietic cells equals to $100 \%$.

\section{Statistical analysis}

Statistical analysis were performed using Graph Pad Prism 5 (GraphPad Software, La Jolla, CA, USA). Quantitative variables are reported as the mean \pm standard deviation (SD). The nonparametric Mann-Whitney ttest was used for the cohorts comparison. Paired t-test was used for the validation of the common gating strategy. A $p$-value $<0.05$ was considered to indicate a statistically significant difference. In addition, to establish the release acceptance criteria, we have chosen the best thresholds achievable in at least $80 \%$ of cases for the parameters which are related to potency.

\section{Results}

\section{Characteristics of donors and AT harvesting}

A total of 364 SVF from 294 patients included in the SSCF cohort and 70 patients included in the AP-HM cohort were available for analysis. Characteristics of donors are summarized in Table 2. AP-HM cohort was composed of a greater proportion of female $(p<0.0001)$ and was slightly older compared to SSCF cohort $(p=$ 0.0570). In AP-HM cohort, only manual AT harvesting was performed whereas in SSCF cohort, the manual harvesting method was used in only $66.30 \%$ of cases. In SSCF cohort, surgeons are free to choose the canula, whereas in AP-HM cohort, only Khouri canula is used. The harvesting area distribution were similar between both cohorts $(p=0.1138)$. The volume of harvested AT was significantly higher $(p<0.0001)$, but less variable in AP-HM cohort than in SSCF cohort with a coefficient of variation of $27.83 \%$ versus $41.85 \%$ and volumes ranging from 100.00 to $340.00 \mathrm{~mL}$ and from 20.00 to $450.00 \mathrm{~mL}$ in AP-HM and SSCF cohorts respectively.

\section{Viability and recovery yield}

SVF viability was higher in SSCF cohort with a mean percentage of $89.33 \% \pm 4.30 \%$ compared to the AP-HM cohort $(84.20 \% \pm 5.96 \%, p<0.0001)$ (Fig. 2A). Recovery yield was also higher in SSCF cohort with an average of $2.54 \times 10^{5} \pm 1.22 \times 10^{5} \mathrm{VNCs}$ extracted per $\mathrm{mL}$ of AT

Table 2 Baseline characteristics of patients. Data are presented as mean \pm SD, or as percentages

\begin{tabular}{|c|c|c|c|}
\hline & SSCF, $n=294$ & AP-HM, $n=70$ & $p$-value \\
\hline Gender, female/male & $60.9 \% / 39.1 \%$ & $88.6 \% / 11.4 \%$ & $<0.0001$ \\
\hline Age, years, mean \pm SD & $49.23 \pm 10.02$ & $51.51 \pm 13.77$ & 0.0566 \\
\hline Volume of the harvested adipose tissue (without the infiltration liquid) & $130.1 \pm 54.45 \mathrm{~mL}$ & $201.9 \pm 56.18 \mathrm{~mL}$ & $<0.0001$ \\
\hline \multicolumn{4}{|l|}{ Harvesting methods } \\
\hline Automatic aspiration & $18.0 \%$ & - & - \\
\hline Manual lipoaspiration (Khouri canula) & - & $100.0 \%$ & \\
\hline Manual lipoaspiration (various canula) & $66.3 \%$ & - & \\
\hline Method for lipoaspiration unknown & $15.6 \%$ & - & \\
\hline \multicolumn{4}{|l|}{ Harvesting area } \\
\hline Abdomen & $37.1 \%$ & $31.4 \%$ & 0.1138 \\
\hline Multiple sites & $26.5 \%$ & $22.9 \%$ & \\
\hline Unknown & $17.3 \%$ & $17.1 \%$ & \\
\hline Flanks & $9.9 \%$ & $5.7 \%$ & \\
\hline Others (back, knee, arm and thighs) & $9.2 \%$ & $22.9 \%$ & \\
\hline
\end{tabular}


compared to $2.25 \times 10^{5} \pm 1.11 \times 10^{5} \mathrm{VNCs}$ recovered in AP-HM cohort ( $p=0.0408)$ (Fig. $2 \mathrm{~B})$.

\section{Microbiological controls and environmental monitoring} AP-HM batches were significantly less contaminated with $95.71 \%$ of sterile batches versus $74.15 \%$ of sterile batches in SSCF cohort $(p<0.0001)$ (Fig. 3A). Regarding in process environmental monitoring, no significant difference could be evidenced between the two manufacturing facilities: $99.80 \%$ (1852 out of 1855) of controls performed at SSCF, and $97.10 \%$ (563 out of 580) of controls performed at AP-HM were found to be free of germs $(p=0.6212)$ (Fig. 3B).

\section{Validation of flow cytometry common gating strategy} A multicenter study was made for validation of flow cytometry experiments. Fourteen SVF batches manufactured using similar manual enzymatic digestion were analyzed using the commonly defined gating strategy and comparing the different antibodies mixes used in the two centers SSCF and AP-HM. In these conditions,

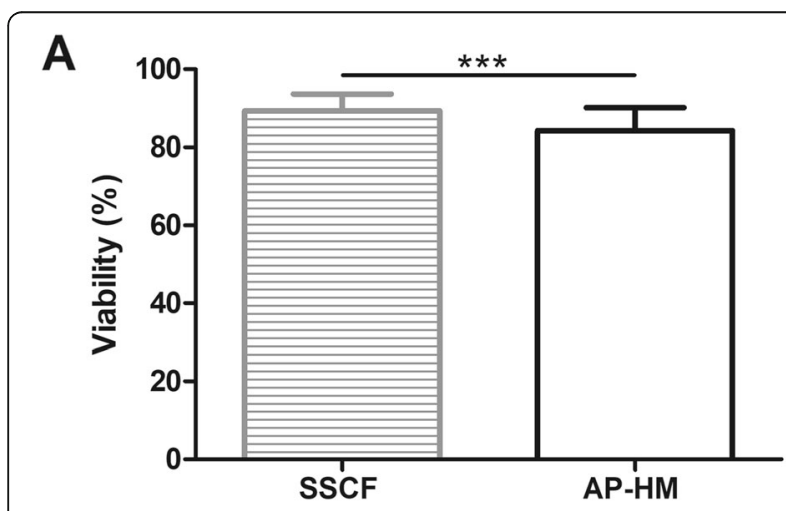

B

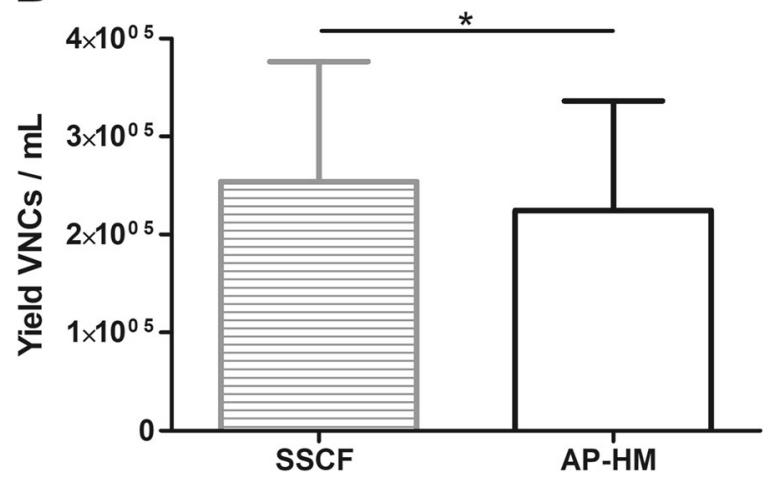

Fig. 2 Comparatives analyses of viability percentage and yield recovery of VNCs/mL AT between the two cohorts. Viability of SVF cells was higher in SSCF cohort compared to AP-HM cohort $(p<$ $0.0001)$. Yield of $\mathrm{VNCs} / \mathrm{mL}$ of AT was higher in SSCF cohort ( $p=$ 0.041). VNC, viable nucleated cell; SSCF, Swiss Stem Cell Foundation; AP-HM, Assistance Publique-Hôpitaux de Marseille; AT, adipose tissue no significant difference could be noted between cell subsets distribution as evidenced by the proportions of ECs $(p=0.7819)$, ASCs $(p=0.7947)$, leukocytes $(p=$ $0.8014)$, and PRs $(p=0.6290)$ determined in the two facilities. (Fig. 4). This result indicates that when the common strategy is used, results from flow cytometry analysis of the SSCF and APHM cohorts can be reliably compared in retrospective analysis.

\section{Cell subset distribution}

Flow cytometry results indicate that the proportion of ECs was significantly higher in SSCF cohort compared to AP-HM cohort $(31.34 \% \pm 16.34 \%$ versus $5.94 \% \pm$ $3.71 \%$ respectively; $p<0.0001$ ). However, no significant difference was observed for ASCs distribution (34.53\% \pm $13.09 \%$ versus $35.52 \% \pm 13.96 \%$; $p=0.5559$ ). Finally, leukocytes and PRs were found in a lower proportion in SVF from SSCF cohort with respective percentages of $29.81 \% \pm 11.41 \%$ and $4.31 \% \pm 3.37 \%$ versus $45.17 \% \pm$ $16.17 \%$ and $12.51 \% \pm 7.67 \%$ for AP-HM cohort $(p<$ 0.0001 and $p<0.0001$ respectively) (Fig. 5).

\section{Proposal for release acceptance criteria thresholds}

In the light of these retrospective data collected by SSCF and AP-HM centers from a large number of therapeutic-grade SVF batches, some essential criteria can be put forward to standardize the release of SVF batches manufactured in compliance with GMP guidelines.

1) Viability of fresh SVF assessed by a cell counter should be equal or superior to $80 \%$.

2) The recovery yield after extraction should be a minimum of $1.50 \times 10^{5} \mathrm{VNCs}$ per $\mathrm{mL}$ of total harvested AT, after removal of the anesthetic infiltration liquid.

3) Proportion of ASCs in the end product should be at least equal to $20 \%$.

4) Proportion of leukocytes in the end product should be less than $50 \%$.

5) Microbiological testing should evidence the sterility of SVF product.

Among the 364 batches of the GMP-SVF analyzed, the viability threshold was reached for $92.90 \%$ of them (representing 338 batches); the recovery yield threshold was acquired for $81.30 \%$ of them (representing 296 batches); $86.80 \%$ of the SVF presented a proportion of ASCs equal or superior to 20\% (representing 316 batches); finally, $87.40 \%$ of the batches demonstrated a proportion of leukocytes under $50.00 \%$ (representing 318 productions). Any center combined, the overall proportion of SVF batches reaching the microbiological attribute is $96.94 \%$. 


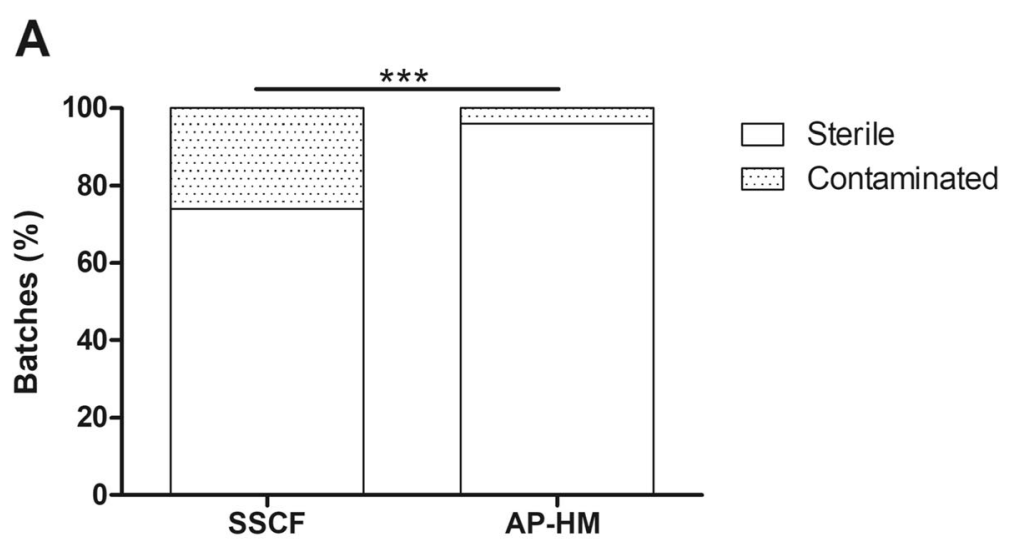

B

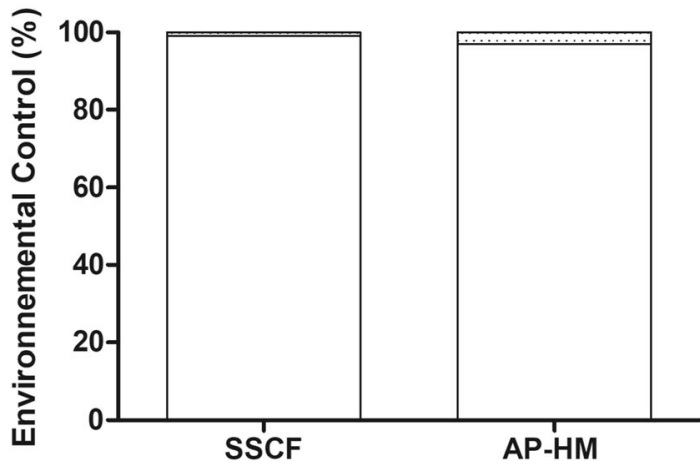

Sterile

Contaminated

Fig. 3 Free of germs and contaminated batches of the finished product and environmental monitoring within the two cohorts. A AP-HM batches were significantly less contaminated compared to SSCF batches $(p=0.0008)$. B No significant differences were observed for environmental monitoring, data missing for 29 patients in SSCF cohort and 12 patients in AP-HM cohort; SSCF, Swiss Stem Cell Foundation; APHM, Assistance Publique-Hôpitaux de Marseille

\section{Discussion}

As far as we know, this study is the first to provide a retrospective analysis of the quality attributes of GMP compliant SVF administered to patients. It takes place in the context of the increasing popularity gained by SVF as an experimental ATMP and its evaluation in many fields of regenerative medicine supported by positive outcomes from early-stage clinical trials. Nonetheless, the heterogeneity of this cell-based product associated to other variability factors such as donor characteristics, manufacturing procedures, or analytical methods have led to a consensus view recommending increased harmonization of quality control and batch release criteria. As specified in appendix B, "considerations for development of final product release criteria specifications and stability protocols" of the guidance for FDA reviewers and sponsors ("Content and Review of Chemistry, Manufacturing, and Control (CMC) Information for Human Somatic Cell Therapy Investigational New Drug Applications (INDs)") [22], the proposed release acceptance criteria should be based on scientific data and manufacturing experience. This referral only mentioned an expected viability rate greater than $70 \%$ for any cellbased product. Former recommendations dedicated to adipose tissue-derived products were provided in 2013 by the International Federation for Adipose Therapeutics and Science (IFATS) and the International Society for Cellular Therapy (ISCT), but mainly concerned the adipose mesenchymal/stromal cells. In addition, they have never been matched to numerous data from reallife use of therapeutic SVF.

Our observation first indicated that the viability and recovery yield of SVF were higher in SSCF cohort when a manual extraction protocol was used. Indeed, the enzymatic digestion automatically performed by the Celution device is shorter than the SSCF digestion and is happening at room temperature whereas the optimal temperature for enzyme activity is $37^{\circ} \mathrm{C}$ [23]. Since 2020, the AP-HM has changed its SVF production protocol for a more efficient manual process [21]. Furthermore, the majority of patients (sixty-two patients) included in the AP-HM cohort presented a chronic 

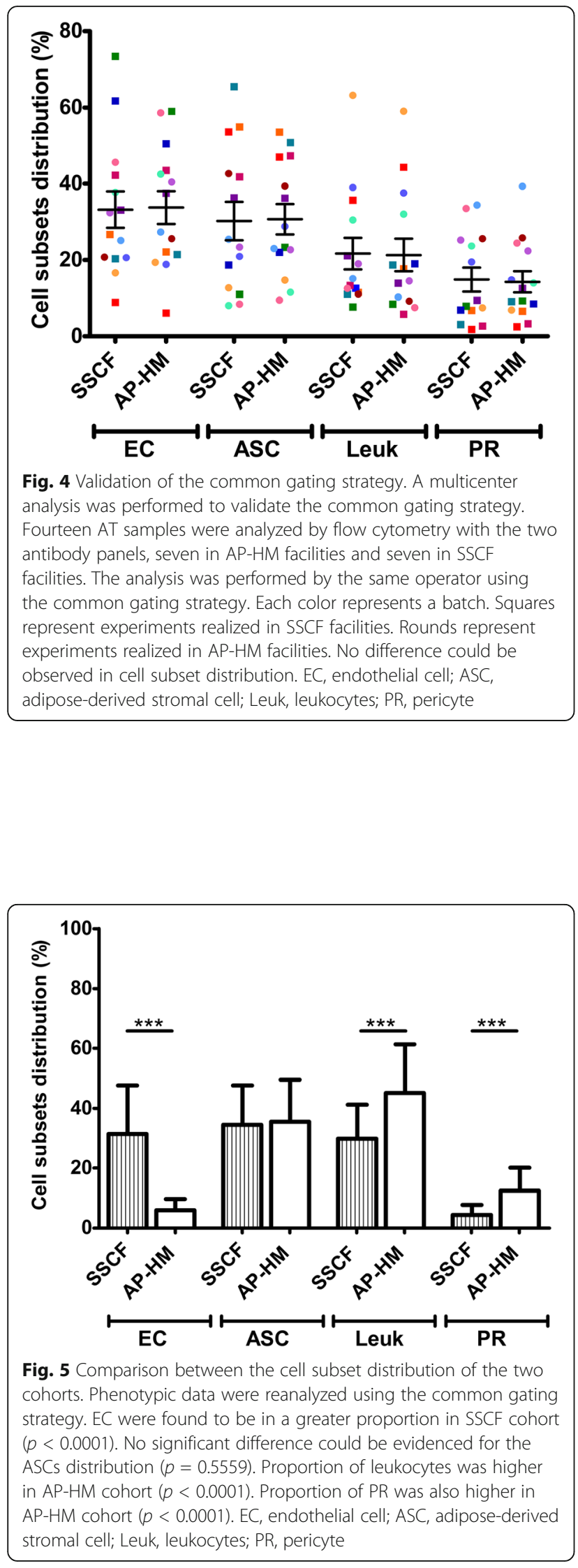

inflammatory disease such as systemic scleroderma or Crohn disease; the SVF may be impacted by this inflammatory signature and that could also explain the lower viability and recovery yield observed in the AP-HM cohort. The size and the shape of adipose tissue harvesting cannulas used are known to influence the biological characteristics of the final SVF and could partly explained the observed differences between SSCF and APHM protocols [5, 6, 24].

Conversely, SVF from AP-HM were significantly less frequently contaminated with $95.71 \%$ of aseptic batches. Although poor data on the microbiological contamination of SVF-based cell therapy products are available, this result is probably explained by a stricter and standardized protocol of skin asepsis before adipose tissue harvesting, implemented according to recommendations from the nosocomial infection control committee from AP-HM. Indeed, AP-HM use a skin decontamination protocol in seven times: application of Betadine scrub (Mylan, Canonsburg, Pa, USA), rinsing with a sterile saline solution, time of drying, application of Betadine scrub again, rinsing with a sterile saline solution, time of drying, and finally application of alcoholic Betadine (Mylan). In addition, patients have two preoperative showers. Furthermore, the AP-HM team carried out ten environmental microbiological monitoring during SVF manufacturing whereas SSCF team performed only four. To date, there is no consensus on the sampling plan (number and nature) of the environmental controls to be performed and each producer should justify the testing strategy based on a risk analysis. The use of the Celution 800/CRS device requires manipulation in a microbiological B class, whereas all the manufacturing process in SSCF facility is performed under a laminar air flow (class A) decreasing the contamination risk and justifying a lower number of in-process controls. This aspect is of importance as environmental controls generate significant costs and the financial sustainability of innovative cell-based therapy remains a well-known challenge [25]. Of note, experience with the SVF consistently shows that the greater contamination risk is coming from the adipose tissue harvesting and the associated break-in of the skin barrier rather than manufacturing environment. So, having clear guidelines seems crucial for that key aspect of SVF manufacturing.

SVF being a heterogeneous mixture of cells, flow cytometry analysis of the various cell subsets is an essential part of the end-product qualification but remains poorly standardized between users. The only ISCT-based recommendations dates from 2013 and has the limitation of only looking at percentages of positivity without identifying all cell subsets. Based on a common flow cytometry gating strategy ensuring comparability of results, we evidenced that the SVF composition was not exactly 
equivalent between the two centers. SVF obtained in SSCF facilities presented more ECs and less leukocytes and PRs. These disparities could be in line with the different production protocols. Beside the efficiency of enzymatic digestion which is dependent on adequate thermostatting, the washing step may introduce significant differences. The washing step is automated and fixed with the Celution device whereas, manually, AT can be washed as much as necessary to maximize the removal of blood cells. In addition, the well-known binding capacity of HSA [26] used to resuspend the final SVF product could nonspecifically influence the immunophenotyping analysis.

However, our work has some limitation regarding analysis of flow cytometry data. Indeed, the absence of size threshold make the interpretation difficult (supplemental figure 1), and the choice of different viability markers leads to the selection of different viable cell populations (supplemental figure 2). This underlines the urgent need to have a robust validation of analytical method according to international council for harmonization (ICH) and GMP for identification of SVF subpopulations. A collaboration between researchers, hospitals, and industries could lead to the development of lyophilized antibody mixes and dedicated kits, which should facilitate the dissemination and general approval of the technique, through the involvement of learned societies.

The deep retrospective analysis and comparison of the SVF produced by SSCF and AP-HM allowed the proposal of release acceptance criteria threshold, achievable in most cases after GMP-compliant production of SVF, whose goal is to standardize practices and upgrade the quality of the future delivered SVF. We identified four essential parameters that should be reported in any publications or researches related to SVF, and to establish the release acceptance criteria, we have chosen the best achievable thresholds in at least $80 \%$ of cases. First, the thresholds for cellular viability $(\geq 80 \%)$ and yield recovery $\left(\geq 1.50 \times 10^{5}\right.$ VNCs per $\left.\mathrm{mL}\right)$ are essential to ensure an acceptable number of delivered viable cells. In $91.5 \%$ of cases, productions started with an initial volume of $\mathrm{AT}$ at least equal to $60 \mathrm{~mL}$. Concerning the composition of the SVF, we propose thresholds for ASCs ( $\geq 20 \%)$ and leukocytes $(\leq 50 \%)$. Historically, ASCs are the cell subset of interest for the regenerative ability of AT [27]. Their implication in the biological mechanisms of SVF has been extensively studied in the context of wound healing [28, 29], angiogenesis [30-32], and scar remodeling [33, 34]. Conversely, except for a few papers reporting the involvement of macrophages in angiogenesis [35-37], the roles of leukocytes is not fully clarified. It seems therefore important to prioritize the presence of the others regenerative cells rather than blood cells. As a matter of fact, endothelial progenitor cells and pericytes have demonstrated their synergistic actions with each other and ASCs [2, 38, 39]. More recently, Kilinc et al. suggested that a 2:1 ratio of ASCs: hematopoietic cells could be a predictive factor for a successful cell therapy procedure using SVF in different conditions [40].

We identified ten articles aiming to compare SVF obtained according different manufacturing protocols [10, $13,16,18,41-46]$. Among them, only two articles reported the four essential parameters mentioned earlier and all of them reach the defined threshold (for Güven and coll.: more than $90 \%$ viability, $1.60 \times 10^{5}$ VNCs per $\mathrm{mL}, 40 \%$ of ASCs and 35\% of leukocytes [16]; for Condé-Green and coll., a viability between 80 and $90 \%$, a yield recovery of $2.30 \times 10^{5} \mathrm{VNCs}$ per $\mathrm{mL}, 60 \%$ of ASCs and $32 \%$ of leukocytes [18]).

Finally, the proposed thresholds for the main criteria related to the final biological product (viability, recovery yield, proportions of stem cells of interest, and leukocytes contaminant) guarantee manufacturing quality. While these criteria have the advantage of being compatible whatever the production method and indication selected, they will certainly have to be refined later on. Indeed, true potency assays aiming to evaluate the functionality of the cells would be the most appropriate method to anticipate the therapeutic efficacy of a batch of FVS. Unfortunately, these tests remain complex to implement and their use is not widely spread. Conversely, the systematic biological characterization initiated in this work is easier and faster to perform in specialized manufacturing centers. From our point of view, reaching the threshold we defined for these classical parameters is the first step to the future identification of potency tests associated. We could anticipate that retrospective analysis of exhaustively characterized SVFs could reveal correlations between the proportion of a cell subset and a specific therapeutic benefit.

\section{Conclusions}

This study identified release acceptance criteria of SVFbased therapeutic product and provides initial data that will participate to the standardization and optimization of manufacturing approaches and could bring new perspectives for cell engineering strategies.

\section{Abbreviations}

AP-HM: Assistance Publique-Hôpitaux de Marseille; AT: Adipose tissue; ASC: Adipose-derived stromal cell; ATMP: Advanced therapy medicinal product; DPBS: Dulbecco's phosphate-buffered saline; EC: Endothelial cell; GMP: Good manufacturing practices; HSA: Human serum albumin; ICH: International council for harmonization; MSC: Mesenchymal stem cell; NC: Nucleated cell; PR: Pericyte; RL: Ringer's lactate; SD: Standard deviation; SSCF: Swiss Stem Cell Foundation; SVF: Stromal vascular fraction; VNC: Viable nucleated cell 


\section{Supplementary Information}

The online version contains supplementary material available at https://doi. org/10.1186/s13287-021-02445-z.

Additional file 1: Supplemental Table 1. Clinical trials of the AP-HM cohort. Detailed of the clinical trials whose patients were included in the study. ANSM : Agence nationale de sécurité du médicament et des produits de santé. Supplemental Table 2. Antibodies references for SSCF and AP-HM protocols. Figure Supplemental 1. Representative images of density plots with or without size scatter threshold. A: Representative density plots of a SVF from SSCF cohort acquired using a flow cytometry protocol with SS threshold and analyzed using the common gating strategy; left: selection of the NC using SS and Syto40; right, discrimination inside CD45- cell population of PR, EC, ASC on the basis of their CD146 and CD34 expression. B: Representative density plots of a SVF from SSCF cohort acquired using a flow cytometry protocol without SS threshold and analyzed using the common gating strategy; left: selection of the NC using SS and a the Syto40, nonspecific events interfered with a strict selection of NC; right: discrimination inside CD45- population of PR, EC, ASC on the basis of their CD146 and CD34 expression, EC and ASC are not clearly discriminated. SSCF: Swiss Stem Cell Foundation. EC: endothelial cell. ASC: adipose-derived stromal cell. Leuk: leukocytes. PR: pericytes. SS: size scatter. NC: nucleated cells. Figure Supplemental 2. Representative images of 7 AAD and DAPI staining. A: Profile of viability with the DAPI marker. B: profile of viability with the 7 AAD marker.

\section{Acknowledgements}

Giulio Rusconi is a PhD student of the "Life Science and Biotechnology" course at University of Insubria.

\section{Authors' contributions}

PF: data analysis and interpretation, manuscript writing. GR: collection and/or assembly of data, therapeutic products manufacturing. LA: data analysis and interpretation. LM: manuscript writing, therapeutic products manufacturing. LG: therapeutic products manufacturing. GM: therapeutic products manufacturing. JV: collection and/or assembly of data. BB: provision of study material or patients. CD: therapeutic products manufacturing. FG: administrative support. LL: data analysis and interpretation. DC: provision of study material or patients. CG: provision of study material or patients. AC: provision of study material or patients. GM: administrative support. FDG: administrative support. FS: administrative support. JM: conception and design. GS: conception and design. The authors read and approved the final manuscript.

\section{Funding}

Not applicable

\section{Availability of data and materials}

The datasets generated and/or analyzed during the current study are not publicly available due to privacy but are available from the corresponding author on reasonable request.

\section{Declarations}

\section{Ethics approval and consent to participate}

The study was conducted in accordance with the Declaration of Helsinki and all subjects provided informed consent for stromal vascular fraction production, and if necessary, studies were approved by national ethics committee review board (supplemental table 1).

\section{Consent for publication}

Not applicable

\section{Competing interests}

The authors have no conflicts of interest to declare.

\section{Author details}

'Cell Therapy Department, Hôpital de la Conception, AP-HM, INSERM CIC BT 1409, 147 Bd Baille, 13005 Marseille, France. ${ }^{2}$ Aix Marseille Univ, INSERM, INRA, C2VN, Marseille, France. ${ }^{3}$ Swiss Stem Cell Foundation, Gentilino,
Lugano, Switzerland. ${ }^{4}$ Department of Biotechnology and Life Sciences, University of Insubria, Varese, Italy. ${ }^{5}$ Vascular Biology Department, Hôpital de la Conception, AP-HM, Marseille, France. ${ }^{6}$ Plastic Surgery Department, Hôpital de la Conception, AP-HM, Marseille, France. ${ }^{7}$ Normandie Univ, UNIROUEN, INSERM, U1234, Rouen University Hospital, Department of Immunology and Biotherapy, Rouen, France. ${ }^{8}$ Assistance Publique-Hôpitaux de Paris, Saint-Louis Hospital, Cell Therapy Unit, Cord blood Bank and CIC-BT501, Paris, France. ${ }^{9}$ Remedex, Marseille, France.

Received: 23 April 2021 Accepted: 10 June 2021

Published online: 01 July 2021

\section{References}

1. Dykstra JA, Facile T, Patrick RJ, Francis KR, Milanovich S, Weimer JM, et al. Concise review: Fat and furious: harnessing the full potential of adiposederived stromal vascular fraction: clinical potential of adipose-derived SVF. Stem Cells Transl Med. 2017;6(4):1096-108. https://doi.org/10.1002/sctm.160337.

2. Bora P, Majumdar AS. Adipose tissue-derived stromal vascular fraction in regenerative medicine: a brief review on biology and translation. Stem Cell Res Ther. 2017;8 Available from: http://stemcellres.biomedcentral.com/a rticles/10.1186/s13287-017-0598-y. Cited 2019 Nov 8.

3. Nguyen A, Guo J, Banyard DA, Fadavi D, Toranto JD, Wirth GA, et al. Stromal vascular fraction: a regenerative reality? Part 1: Current concepts and review of the literature. J Plast Reconstr Aesthet Surg. 2016;69(2):170-9. https://doi. org/10.1016/j.bjps.2015.10.015

4. Bourin P, Bunnell BA, Casteilla L, Dominici M, Katz AJ, March KL, et al. Stromal cells from the adipose tissue-derived stromal vascular fraction and culture expanded adipose tissue-derived stromal/stem cells: a joint statement of the International Federation for Adipose Therapeutics and Science (IFATS) and the International Society for Cellular Therapy (ISCT). Cytotherapy. 2013;15(6):641-8. https://doi.org/10.1016/j.jcyt.2013.02.006.

5. Travnickova M, Pajorova J, Zarubova J, Krocilova N, Molitor M, Bacakova L. The influence of negative pressure and of the harvesting site on the characteristics of human adipose tissue-derived stromal cells from lipoaspirates. Stem Cells Int. 2020, 2020; Available from: https://www.ncbi. nlm.nih.gov/pmc/articles/PMC7035580/. Cited 2020 Mar 17.

6. Bajek A, Gurtowska N, Olkowska J, Maj M, Kaźmierski Ł, Bodnar M, et al. Does the harvesting technique affect the properties of adipose-derived stem cells?-The comparative biological characterization: influence of harvesting method on properties of ADSCs. J Cell Biochem. 2017;118(5): 1097-107. https://doi.org/10.1002/jcb.25724.

7. Bony C, Cren M, Domergue S, Toupet K, Jorgensen C, Noël D. Adipose mesenchymal stem cells isolated after manual or water-jet-assisted liposuction display similar properties. Front Immunol. 2016;6 Available from: https://www.ncbi.nlm.nih.gov/pmc/articles/PMC4716140/. Cited 2020 Jul 26.

8. Li Z, Mu D, Liu C, Xin M, Fu S, Li S, et al. The cell yields and biological characteristics of stromal/stem cells from lipoaspirate with different digestion loading ratio. Cytotechnology. 2020;72(2):203-15. https://doi.org/1 0.1007/s10616-020-00369-9.

9. Lee SJ, Lee CR, Kim KJ, Ryu YH, Kim E, Han YN, et al. Optimal condition of isolation from an adipose tissue-derived stromal vascular fraction for the development of automated systems. Tissue Eng Regen Med. 2020;17(2): 203-8. https://doi.org/10.1007/s13770-019-00238-3.

10. Domenis R, Lazzaro L, Calabrese S, Mangoni D, Gallelli A, Bourkoula E, et al. Adipose tissue derived stem cells: in vitro and in vivo analysis of a standard and three commercially available cell-assisted lipotransfer techniques. Stem Cell Res Ther. 2015;6(1):2. https://doi.org/10.1186/scrt536.

11. Rodriguez J, Pratta A-S, Abbassi N, Fabre H, Rodriguez F, Debard C, et al. Evaluation of three devices for the isolation of the stromal vascular fraction from adipose tissue and for ASC culture: a comparative study. Stem Cells Int. 2017;2017:1-14. https://doi.org/10.1155/2017/9289213.

12. Oberbauer E, Steffenhagen C, Wurzer C, Gabriel C, Redl H, Wolbank S. Enzymatic and non-enzymatic isolation systems for adipose tissue-derived cells: current state of the art. Cell Regen. 2015;4:7.

13. Gentile P, Calabrese C, De Angelis B, Pizzicannella J, Kothari A, Garcovich S Impact of the different preparation methods to obtain human adiposederived stromal vascular fraction cells (AD-SVFs) and human adiposederived mesenchymal stem cells (AD-MSCs): enzymatic digestion versus mechanical centrifugation. Int J Mol Sci. 2019;20 Available from: https:// www.ncbi.nlm.nih.gov/pmc/articles/PMC6862236/. Cited 2020 Apr 8. 
14. van Dongen JA, Tuin AJ, Spiekman M, Jansma J, van der Lei B, Harmsen MC. Comparison of intraoperative procedures for isolation of clinical grade stromal vascular fraction for regenerative purposes: a systematic review: Intraoperative procedures for stromal vascular fraction isolation. J Tissue Eng Regen Med. 2018;12(1):e261-74. https://doi.org/10.1002/term.2407.

15. Yoshimura K, Shigeura T, Matsumoto D, Sato T, Takaki Y, Aiba-Kojima E, et al. Characterization of freshly isolated and cultured cells derived from the fatty and fluid portions of liposuction aspirates. J Cell Physiol. 2006;208(1):64-76. https://doi.org/10.1002/jcp.20636.

16. Güven S, Karagianni M, Schwalbe M, Schreiner S, Farhadi J, Bula S, et al. Validation of an automated procedure to isolate human adipose tissuederived cells by using the Sepax ${ }^{\circledast}$ technology. Tissue Eng Part C Methods. 2012;18(8):575-82. https://doi.org/10.1089/ten.tec.2011.0617.

17. Bianchi F, Maioli M, Leonardi E, Olivi E, Pasquinelli G, Valente S, et al. A new nonenzymatic method and device to obtain a fat tissue derivative highly enriched in pericyte-like elements by mild mechanical forces from human lipoaspirates. Cell Transplant. 2013;22(11):2063-77. https://doi.org/10.3727/ 096368912X657855 SAGE Publications Inc.

18. Condé-Green A, Rodriguez RL, Slezak S, Singh DP, Goldberg NH, McLenithan J. Comparison between stromal vascular cells' isolation with enzymatic digestion and mechanical processing of aspirated adipose tissue. Plast Reconstr Surg. 2014;134:54

19. SundarRaj S, Deshmukh A, Priya N, Krishnan VS, Cherat M, Majumdar AS. Development of a system and method for automated isolation of stromal vascular fraction from adipose tissue lipoaspirate. Stem Cells Int. 2015;2015 Available from: https://www.ncbi.nlm.nih.gov/pmc/articles/PMC4475713/. Cited 2020 Apr 8.

20. Zimmerlin L, Rubin JP, Pfeifer ME, Moore LR, Donnenberg VS, Donnenberg AD. Human adipose stromal vascular cell delivery in a fibrin spray. Cytotherapy. 2013;15(1):102-8. https://doi.org/10.1016/j.jcyt.2012.10.009.

21. François P, Giraudo L, Veran J, Bertrand B, Dumoulin C, Aboudou H, et al. Development and validation of a fully GMP-compliant process for manufacturing stromal vascular fraction: a cost-effective alternative to automated methods. Cells. 2020;9(10):2158. https://doi.org/10.3390/cells91 02158.

22. Guidance for FDA Reviewers and Sponsors: Content and Review of Chemistry, Manufacturing, and Control (CMC) Information for Human Somatic Cell Therapy Investigational New Drug Applications (INDs). https:// www.fda.gov/regulatoryinformation/search-fda-guidance-documents/ content-and-review-chemistry-manufacturing-and-control-cmc-informationhuman-somatic-cell-therapy.

23. Fraser JK, Hicok KC, Shanahan R, Zhu M, Miller S, Arm DM. The Celution ${ }^{\circledR}$ System: automated processing of adipose-derived regenerative cells in a functionally closed system. Adv Wound Care. 2014;3(1):38-45. https://doi. org/10.1089/wound.2012.0408.

24. Iyyanki T, Hubenak J, Liu J, Chang El, Beahm EK, Zhang Q. Harvesting technique affects adipose-derived stem cell yield. Aesthet Surg J. 2015;35(4): 467-76. https://doi.org/10.1093/asj/sju055.

25. ten Ham RMT, Hoekman J, Hövels AM, Broekmans AW, Leufkens HGM Klungel $\mathrm{OH}$. Challenges in advanced therapy medicinal product development: a survey among companies in Europe. Mol Ther - Methods Clin Dev. 2018;11:121-30. https://doi.org/10.1016/j.omtm.2018.10.003.

26. Fasano M, Curry S, Terreno E, Galliano M, Fanali G, Narciso P, et al. The extraordinary ligand binding properties of human serum albumin. IUBMB Life. 2005;57(12):787-96. https://doi.org/10.1080/15216540500404093.

27. Zuk PA, Zhu M, Ashjian P, De Ugarte DA, Huang JI, Mizuno H, et al. Human adipose tissue is a source of multipotent stem cells. Mol Biol Cell. 2002; 13(12):4279-95. https://doi.org/10.1091/mbc.e02-02-0105.

28. Paganelli A, Benassi L, Rossi E, Magnoni C. Extracellular matrix deposition by adipose-derived stem cells and fibroblasts: a comparative study. Arch Dermatol Res. 2020;312(4):295-9. https://doi.org/10.1007/s00403-019-01997-8.

29. Díaz-Flores L, Gutiérrez R, Lizartza K, Goméz MG, García MDP, Sáez FJ, et al. Behavior of in situ human native adipose tissue CD34+ stromal/progenitor cells during different stages of repair. Tissue-Resident CD34+ Stromal Cells as a Source of Myofibroblasts: human adipose stromal cells during repair. Anat Rec. 2015;298(5):917-30. https://doi.org/10.1002/ar.23086.

30. Rehman J, Traktuev D, Li J, Merfeld-Clauss S, Temm-Grove CJ, Bovenkerk JE, et al. Secretion of angiogenic and antiapoptotic factors by human adipose stromal cells. Circulation. 2004;109(10):1292-8. https://doi.org/10.1161/01.CIR. 0000121425.42966.F1.
31. Nakagami H, Maeda K, Morishita R, Iguchi S, Nishikawa T, Takami Y, et al. Novel autologous cell therapy in ischemic limb disease through growth factor secretion by cultured adipose tissue-derived stromal cells. Arterioscler Thromb Vasc Biol. 2005;25(12):2542-7. https://doi.org/10.1161/01.ATV.00001 90701.92007.6d.

32. Ramakrishnan VM, Tien KT, McKinley TR, Bocard BR, McCurry TM, Williams SK, et al. Wnt5a regulates the assembly of human adipose derived stromal vascular fraction-derived microvasculatures. PLoS One. 2016;11:e0151402 Ribatti D, editor.

33. Deng CL, Li XQ, Liu ZY, Yao YZ, Wei ZR, Wang DL. Effects of local transplantation of autologous adipose-derived stromal vascular fraction on the hyperplastic scar formation in rabbit ears and the mechanism. Zhonghua Shao Shang Za Zhi Zhonghua Shaoshang Zazhi Chin J Burns. 2018;34:542-8.

34. Gumucio JP, Flood MD, Roche SM, Sugg KB, Momoh AO, Kosnik PE, et al. Stromal vascular stem cell treatment decreases muscle fibrosis following chronic rotator cuff tear. Int Orthop. 2016;40(4):759-64. https://doi.org/10.1 007/s00264-015-2937-x.

35. Dong Z, Fu R, Liu L, Lu F. Stromal vascular fraction (SVF) cells enhance longterm survival of autologous fat grafting through the facilitation of $M 2$ macrophages: stromal vascular fraction (SVF) cells enhance long-term. Cell Biol Int. 2013;37(8):855-9. https://doi.org/10.1002/cbin.10099.

36. Cai J, Feng J, Liu K, Zhou S, Lu F. Early macrophage infiltration improves fat graft survival by inducing angiogenesis and hematopoietic stem cell recruitment. Plast Reconstr Surg. 2018;141(2):376-86. https://doi.org/10.1 097/PRS.0000000000004028.

37. Navarro A, Marín S, Riol N, Carbonell-Uberos F, Miñana M. Human adipose tissue-resident monocytes exhibit an endothelial-like phenotype and display angiogenic properties. Stem Cell Res Ther. 2014;5(2):50. https://doi.org/10.11 86/scrt438.

38. Errede M, Mangieri D, Longo G, Girolamo F, de Trizio I, Vimercati A, et al. Tunneling nanotubes evoke pericyte/endothelial communication during normal and tumoral angiogenesis. Fluids Barriers CNS. 2018;15(1):28. https:// doi.org/10.1186/s12987-018-0114-5.

39. Planat-Benard V, Silvestre J-S, Cousin B, André M, Nibbelink M, Tamarat R, et al. Plasticity of human adipose lineage cells toward endothelial cells: physiological and therapeutic perspectives. Circulation. 2004;109(5):656-63. https://doi.org/10.1161/01.CIR.0000114522.38265.61.

40. Kilinc MO, Santidrian A, Minev I, Toth R, Draganov D, Nguyen D, et al. The ratio of ADSCs to HSC-progenitors in adipose tissue derived SVF may provide the key to predict the outcome of stem-cell therapy. Clin Transl Med. 2018;7(1):5 Available from: https://onlinelibrary.wiley.com/doi/abs/1 0.1186/s40169-018-0183-8. Cited 2021 Jan 20.

41. Millan A, Landerholm, Chapman. Comparison between collagenase adipose digestion and Stromacell mechanical dissociation for mesenchymal stem cell separation.

42. Baptista LS, do Amaral RJFC, Carias RBV, Aniceto M, Claudio-da-Silva C, Borojevic R. An alternative method for the isolation of mesenchymal stromal cells derived from lipoaspirate samples. Cytotherapy. 2009;11:706-15.

43. Shah FS, Wu X, Dietrich M, Rood J, Gimble JM. A non-enzymatic method for isolating human adipose tissue-derived stromal stem cells. Cytotherapy. 2013;15(8):979-85. https://doi.org/10.1016/j.jcyt.2013.04.001.

44. Markarian CF, Frey GZ, Silveira MD, Chem EM, Milani AR, Ely PB, et al. Isolation of adipose-derived stem cells: a comparison among different methods. Biotechnol Lett. 2014;36(4):693-702. https://doi.org/10.1007/s1052 9-013-1425-X.

45. Aronowitz JA, Lockhart RA, Hakakian CS. Mechanical versus enzymatic isolation of stromal vascular fraction cells from adipose tissue. SpringerPlus. 2015;4 Available from: http://www.springerplus.com/content/4/1/713. Cited 2019 Feb 21.

46. Doi K, Tanaka S, lida H, Eto H, Kato H, Aoi N, et al. Stromal vascular fraction isolated from lipo-aspirates using an automated processing system: bench and bed analysis. J Tissue Eng Regen Med. 2013;7(11):864-70. https://doi. org/10.1002/term.1478.

\section{Publisher's Note}

Springer Nature remains neutral with regard to jurisdictional claims in published maps and institutional affiliations. 